\title{
Enzymatic Responses of Ginger Plants to Pythium Infection after SAR Induction
}

\section{Rajyasri Ghosh*}

Mycology and Plant Pathology Laboratory, Department of Botany, Scottish Church College, Kolkata, India

\begin{abstract}
A variety of enzymatic responses of ginger plants to Pythium infection after induction of SAR (systemic acquired resistance) have been investigated. Results of pathogenicity test of $P$. aphanidermatum on a susceptible ginger cultivar showed that disease intensity increased with time up to 28 days but Polyphenol oxidase (PPO), Lipoxygenase (LOX) and Phenyl alanine ammonia lyase (PAL) activities increased up to 14 days following inoculation and then declined whereas Peroxidase (PO) activity reached their peaks on $21^{\text {st }}$ day after inoculation and then decreased sharply. To induce SAR, rhizome seeds were soaked separately in salicylic acid (SA-5 mM) and Acalypha leaf extract (ALE - 10\%) for 1 hour prior to sowing. Significant disease reduction was observed in both SA and ALE treated plants. SA and ALE treatment enhanced activities of all four defence related enzymes in ginger leaves but the rate of increase was higher in untreated inoculated and treated non-inoculated plants in relation to their respective controls. Treated inoculated plants exhibited maximum activity for all four enzymes. SA stimulated PO and PAL more than that of ALE. Results suggest that a correlation exists between reduction of disease intensity due to SAR induction and greater stimulation of specific enzymatic activities in ginger plants although not all four enzymes are equally responsive to a defence activator.
\end{abstract}

Keywords: Ginger; Pythium aphanidermatum; Salicylic acid; Acalypha leaf extract; Defence related enzyme; SAR

\section{Introduction}

Induced resistance is defined as an enhancement of the plant defensive capacity against a broad spectrum of pathogens and pests that is acquired after appropriate stimulation. The resulting elevated resistance due to an inducing agent upon infection by a pathogen is called ISR or SAR [1]. Induction of resistance in plants to a broad spectrum of microorganisms by different plant defence activators and involvement of defence related proteins and enzymes have been discussed earlier in detail [2-5]. Various biotic and abiotic inducers can also enhance the activities of defence related enzymes, Two different biotic inducers [Pseudomonas fluorescens and Pseudomonas putida] and three different abiotic inducers [copper sulphate, indole butyric acid and potassium chloride] were tested for their efficacy in inducing resistance in lupin plants against Fusarium wilt disease caused by Fusarium oxysporum f. sp. Lupine. A time course of defence-related enzymes showed substantial increases in enzyme activities in induced infected seedlings compared with untreated healthy plants or infected controls [6]. Induction of defense-related marker enzyme activity, namely, peroxidase, polyphenol oxidase, $\beta-1,3$ glucanase, chitinase, and phenolics was observed in banana (Grand Naine variety) plants when interacting with dead or live pathogen, Fusarium oxysporum $f$. sp. cubense, a causative agent of Panama disease [7]. These defence related enzymes are associated with the biosynthesis of lignin, phenolic compounds and phytoalexins, which are considered as important plant, defence components. Therefore, their role in induced resistance is significant. Peroxidase (PO) oxidizes phenolics to quinones and generates $\mathrm{H}_{2} \mathrm{O}_{2}$. The latter not only is antimicrobial in itself, but it also releases highly reactive free radicals and in that way further increases the rate of polymerization of phenolic compounds into lignin like compounds. These substances are deposited in cell walls and papillae and inhibited further growth and development of pathogen. Increased activity of polyphenol oxidase (PPO) also results in accumulation of higher concentrations of toxic products of oxidation and therefore greater degree of resistance to infection occurs. In contrast to peroxidase and polyphenol oxidase, lipoxygenases (LOX) use molecular oxygen to oxygenate unsaturated fatty acids such as linoleic acid, linolenic acid producing fatty acid hydroperoxide [8,9]. Lipoxygenases are primarily induced by pathogen attack and to a lesser extent by wounding and herbivore damage [9]. This enzyme has several important roles in defe $\mathrm{e}^{\text {twx }} \mathrm{nce}$, for example, LOX are required for the synthesis of jasmonates that has a major role in defence. Phenylalanine ammonia lyase (PAL), one of the key enzymes in the phenyl propanoid pathway, has a role in phytoalexin, phenolic compound and salicylic acid synthesis. Other defense related enzymes include pathogenesis related proteins (PRs) such as $\beta$-1,3-glucanase (PR2) and chitinase (PR1) which degrade fungal cell wall and cause cell lysis.

Recent studies on host pathogen interactions revealed the existence of SAR in non-vascular plants. Andersson et al. [10] reported SAdependent defense pathway in Physcomitrella patens against Erwinia ceratovora. Ponce de Leon et al. demonstrated that treatment of whole plant of $P$. patens with elicitors or cell-free culture filtrates of the bacterium Erwinia carotovora or inoculation with spores of the fungus Botrytis cinerea altered expression of the genes PR-1, CHS, $P A L$, and $L O X$, which are all up-regulated upon pathogen attack in vascular plants. Oliver et al. [11] showed that $P$. patens activated multiple and similar responses against Pythium irregulare and Pythium debaryanum, including the reinforcement of the cell wall, induction of the defense genes CHS, LOX and PAL, and accumulation of the signaling molecules jasmonic acid (JA) and its precursor 12-oxophytodienoic acid (OPDA). This study indicated that in $P$. patens, Pythium infection activates common responses to those previously characterized in flowering plants. Winter et al. [12] demonstrated moss species Amblystegium serpens could initiate SAR like reactions upon inoculation with Pythium irregulare. Results of their investigation,

${ }^{*}$ Corresponding author: Rajyasri Ghosh, Assistant professor, Mycology and Plant Pathology laboratory, Department of Botany, Scottish Church College, Kolkata, India, Tel: 9433985015; E-mail: rajyasri_5@rediffmail.com

Received April 29, 2015; Accepted July 02, 2015; Published July 14, 2015

Citation: Ghosh R (2015) Enzymatic Responses of Ginger Plants to Pythium Infection after SAR Induction. J Plant Pathol Microb 6: 283. doi:10.4172/21577471.1000283

Copyright: (c) 2015 Ghosh R. This is an open-access article distributed under the terms of the Creative Commons Attribution License, which permits unrestricted use, distribution, and reproduction in any medium, provided the original author and source are credited. 
together with previous studies, suggest that SAR arose prior to the divergence of vascular and non-vascular plants.

Ginger occupies an important place in plantation crops and is grown in tropical and subtropical regions of the country for its aromatic rhizomes, which are used both as a spice and as a medicine. Rhizome rot caused by Pythium aphanidermatum is a serious disease of ginger, which causes considerable loss in yield every year. In the present investigation an attempt has been made to study the specific enzymatic responses of ginger plants to Pythium aphanidermatum after induction of resistance by two plant defence activators. The purpose of this study is to determine how far defence related enzymes such as PO, PPO, LOX and PAL activities are affected by SAR induction in ginger.

\section{Materials and Methods}

\section{Source of ginger and fungal culture}

Rhizome seeds (cultivar Suprabha) were collected from Amtala seed stores, South 24 Parganas, West Bengal. The culture of Pythium aphanidermatum (Edson) Fitz, a causal organism of rhizome rot or soft rot disease of ginger was supplied by the Indian Institute of Spices Research, Calicut, Kerala.

\section{Pathogenicity test}

Healthy rhizome seeds of ginger were disinfected and sown in earthenware pots (one rhizome seed/pot of $20 \mathrm{~cm}$ diameter) containing non-infected sandy soil (sand: soil: 1:3). The plants were kept under ordinary conditions of daylight, temperature $\left(28-34^{\circ} \mathrm{C}\right)$ and humidity (77-85\%) of the experimental garden of the Department of Botany. Water supply was maintained once a day except during rainy days. The top soil in pots was inoculated with $P$. aphanidermatum (in sand maize meal) after 28 days of sowing rhizome seeds following the method of Karmakar et al. [13]. Disease intensity was assessed usually 4 weeks after inoculation and 8 weeks after sowing rhizome seeds. Yellowing of leaves is one of the important symptoms of rhizome rot disease of ginger and hence yellowing index (Y.I.)/plant was calculated as follows:

\section{Y.I. / Plant $=\frac{\text { Total number of leaves showing yellowing symptom }}{\text { Total }}$ Total number of test plants / treatment}

Apart from Y.I./Plant, percentage loss in fresh weight of rhizomes due to putrifaction caused by the pathogen was also estimated in relation to non-inoculated control.

\section{Method of application of plant defence activators}

To induce resistance in ginger plants rhizome seeds are soaked separately in salicylic acid (SA) and 10\% leaf extract of Acalypha indica (ALE) for 1 hour prior to sowing. Control seeds were soaked in distilled water for a similar period. The leaf extract was prepared following the method of Doubrava et al. [14]. The leaves were homogenized with distilled water $(50 \mathrm{~g}$ fresh weight of leaves $/ 100 \mathrm{ml})$ in an electric blender. The homogenate was strained through two layers of muslin and the filtrate centrifuged at 5,000 $\mathrm{x}$ g for 15 minutes at $4^{\circ} \mathrm{C}$. Usually, $100 \mathrm{ml}$ of supernatant $(50 \%)$ were added to $500 \mathrm{ml}$ distilled water (1: 5 ), mixed thoroughly and used for treating rhizome seeds by soaking method.

\section{Extraction and assay of enzymes}

PO: Extraction and assay of PO from ginger leaves were carried out following the method of Sadashivam and Manickam [15] with modifications. PO was extracted from ginger leaves with $0.1 \mathrm{M}$ phosphate buffer, $\mathrm{pH} 7.0\left(2 \mathrm{ml} \mathrm{g}^{-1}\right.$ fresh tissue $)$ by grinding the leaves in a prechilled mortar and pestle with sea sand. The extract was strained through muslim and centrifuged at $15,000 \mathrm{rpm}$. for $15 \mathrm{~min}$ at $4^{\circ} \mathrm{C}$. The supernatant was used as enzyme source.

For enzyme assay, $200 \mu \mathrm{l}$ of enzyme extract was added to $3.5 \mathrm{ml}$ of phosphate buffer ( $\mathrm{pH}$ 6.5) and to this mixture $0.1 \mathrm{ml}$ freshly prepared o-dianisidine solution $\left(1 \mathrm{mg} \mathrm{ml}^{-1}\right.$ methanol) was added. The assay mixture was brought to $28-30^{\circ} \mathrm{C}$ and the reaction started after addition of $0.2 \mathrm{ml}(0.2 \mathrm{M}) \mathrm{H}_{2} \mathrm{O}_{2}$ to the mixture. The initial $\mathrm{OD}$ at $436 \mathrm{~nm}$ was noted and then readings were taken at an interval of $30 \mathrm{sec}$ up to $3 \mathrm{~min}$. A water blank was also included in the assay. The enzyme activity was expressed as change in OD (optical density) at $436 \mathrm{~nm}$ per unit time per mg protein.

PPO: PPO activity was measured following the method of Sadashivam and Manickam [15] with modifications. For enzyme extraction, leaf tissues of ginger were homogenized in $50 \mathrm{mM}$ Tris$\mathrm{HCl}$ buffer, pH $7.2\left(2 \mathrm{ml} \mathrm{g}^{-1}\right.$ tissue). The homogenate was strained through muslin, centrifuged at $15,000 \mathrm{rpm}$ for $10 \mathrm{~min}$ at $4^{\circ} \mathrm{C}$ and the supernatant was used as enzyme extract.

For enzyme assay $0.6 \mathrm{ml}$ catechol solution $(0.01 \mathrm{M})$ was first added to $5 \mathrm{ml}$ phosphate buffer $(0.1 \mathrm{M}, \mathrm{pH}$ 6.5) and then $1 \mathrm{ml}$ enzyme extract was supplemented to this mixture. The change in optical density was recorded at $490 \mathrm{~nm}$ for every 30 seconds up to $3 \mathrm{~min}$. The enzyme activity was expressed as change in OD at $490 \mathrm{~nm}$ per unit time per mg protein.

LOX: For extraction and assay of LOX activity the method of Vick and Zimmermann [16] was adopted with modifications. LOX was extracted from ginger leaves using potassium phosphate buffer $(0.05$ $\mathrm{M}, \mathrm{pH}$ 6.0). The homogenate was filtered and centrifuged at 15,000 rpm for $15 \mathrm{~min}$ at $4^{\circ} \mathrm{C}$ and the supernatant was used for LOX assay. LOX activity was measured spectrophotometrically using linoleic acid as substrate. Hundred microlitres of crude enzyme extract was added to $2.9 \mathrm{ml}$ potassium phosphate buffer $(0.05 \mathrm{M}, \mathrm{pH} 6.0)$. The reaction was initiated by $20 \mu$ of linoleic acid $(8 \mathrm{mM})$ substrate at room temperature $\left(30^{\circ} \mathrm{C}\right)$. LOX activity was measured by conjugated diene absorption of the hydroperoxide at $234 \mathrm{~nm}$. The enzyme activity was expressed as $\mu \mathrm{mol}$ conjugated diene produced per unit time per mg protein.

PAL: For extraction and assay of PAL, the method described by Smith et al. [17] was followed. Ginger leaf tissues were homogenized in $50 \mathrm{mM}$ Tris- $\mathrm{HCl}$ buffer ( $\mathrm{pH} 8.6)$ containing $10 \mathrm{mM}$ ascorbic acid $(3 \mathrm{ml}$ $\mathrm{g}^{-1}$ fresh weight) with a mortar and pestle. The homogenate was filtered, centrifuged at 15,000 r.p.m for $20 \mathrm{~min}$ at $4^{\circ} \mathrm{C}$ and the supernatant dialysed against $50 \mathrm{mM}$ Tris- $\mathrm{HCl}(\mathrm{pH} 8.6)$ for $16 \mathrm{~h}$ at $4^{\circ} \mathrm{C}$.

The dialysate was assayed spectrophotometrically for PAL activity after addition of $1 \mathrm{ml}$ of $30 \mathrm{mM} \mathrm{L}$-phenylalanine (dissolved in appropriate volume of $50 \mathrm{mM}$ Tris- $\mathrm{HCl}, \mathrm{pH} 8.6$ ) and $2 \mathrm{ml}$ of dialysate (protein content $1 \mathrm{mg} / \mathrm{ml}$ ). Absorbance was measured at 290 $\mathrm{nm}$ in Shimadzu UV-160A spectrophotometer after $2 \mathrm{~h}$ incubation at $30^{\circ} \mathrm{C}$. A control was maintained for a similar period using $10 \mathrm{mM}$ D-phenylalanine instead of L-isomer. The activity was expressed as the amount of cinnamic acid $(\mu \mathrm{mol})$ produced per unit time per $\mathrm{mg}$ protein.

\section{Result and Discussion}

\section{Pathogenicity test}

Disease severity was assessed after $7,14,21$ and 28 days of inoculation. Initially, symptoms developed on leaves as slight fading of green colour followed by yellowing of leaf tips (chlorosis) that 
Citation: Ghosh R (2015) Enzymatic Responses of Ginger Plants to Pythium Infection after SAR Induction. J Plant Pathol Microb 6: 283. doi:10.4172/2157-7471.1000283

Page 3 of 6

extended downwards resulting in withering and drying of leaves. Rhizomes became soft and gradually the internal tissues rot completely (putrefaction), plants showed wilting symptoms and finally collapsed. It appears from the results that the intensity of disease increased with time up to 28 days following inoculation. About $34 \%$ loss in fresh weight of rhizomes was noted. Yellowing index/plant also increased with time up to 28 days. Significant difference in percentage weight loss was recorded between 14 and 21 days $(\mathrm{P}<0.01)$ and also between 21 and 28 days $(\mathrm{P}<0.05)$ of inoculation. Difference was not significant between 7 and 14 days in terms of weight loss. Statistical analysis of data shows a positive correlation $(\mathrm{P}<0.05)$ between intensity of disease and duration of incubation time up to 28 days following inoculation (Table 1 and Figure 1).

\section{Effect of incubation period on enzyme activity}

Defence related enzymes (PO, PPO, LOX and PAL) were extracted from leaves of ginger plants after 7, 14, 21 and 28 days of inoculation in all cases after assessment of disease intensity. The enzyme activities were assayed as described and results are given in Figure 2A-2D.

$\mathrm{PO}$ activity increased in leaves of untreated inoculated plants up to 21 days of inoculation and then declined sharply (Figure 2A). Whereas PPO activity increased and reached its peak on the 14th day of inoculation and then declined gradually in leaves of untreated inoculated plants (Figure 2B). Significant differences $(\mathrm{P}<0.01)$ in enzyme activities were noted between 7 and 14, 14 and 21 and also between 21 and 28 days of inoculation in case of both PO and PPO. The LOX activity also increased in leaves of untreated inoculated plants up to 14 days following inoculation and then declined (Figure 2C). Differences in enzyme activities were significant $(\mathrm{P}<0.01)$ between 14 and 21 and also between 21 and 28 days but not between 7 and 14 days. The PAL activity also increased up to 14 days and then declined in leaves of untreated inoculated plants. There is a significant $(\mathrm{P}<0.01)$ decrease in enzyme activity between 14 and 21 days but not between 21 and 28 days (Figure 2D). Activities of all four enzymes increased in leaves of untreated inoculated plants as follows: PO (4-fold), PPO (4.2fold), LOX (3.2-fold), and PAL (5-fold).

Results revealed that incubation period has significant effect on disease development and enzyme activities. But there is no direct correlation between the rate of enzyme activity and intensity of disease.

\section{Effects of plant defence activators (SA and ALE) on disease development}

Effects of two plant defence activators (SA and ALE) were tested on disease development and enzyme (PO, PPO, LOX and PAL) activities in ginger. Healthy rhizome seeds were soaked separately in $5 \mathrm{mM} \mathrm{SA}$ and $10 \%$ ALE for $1 \mathrm{~h}$ prior to sowing. Plants were inoculated as usual after 28 days of sowing and disease severity was assessed after 14 and 28 days of inoculation. Results indicated that both SA and ALE reduced disease significantly $(\mathrm{P}<0.01)$. The difference between SA and ALE treatments in terms of percentage loss in fresh weight of rhizomes, even after 28 days of inoculation was not significant (Table 2).

\section{Effects of plant defence activators (SA and ALE) on enzyme (PO, PPO, LOX and PAL) activities}

After assessment of disease intensity on 14th and 28th day of inoculation, enzyme were extracted from leaves of untreated and treated non-inoculated and inoculated ginger plants and assayed. The results are given in Table 3.

It is evident from the results that both SA and ALE enhanced PO activity in leaves of non-inoculated and inoculated ginger plants but markedly in treated inoculated ones. Enzyme activity decreased on 28th day of inoculation in all cases except untreated non-inoculated plants. The difference in PO activity between SA and ALE-treated plants was significant $(\mathrm{P}<0.01)$ on 14 th day but not significant on 28th day of inoculation. Like PO, PPO activity also increased in leaves of SA and ALE-treated non-inoculated and inoculated plants up to 14 days of inoculation. The rate of increase was significantly higher $(\mathrm{P}<0.05)$
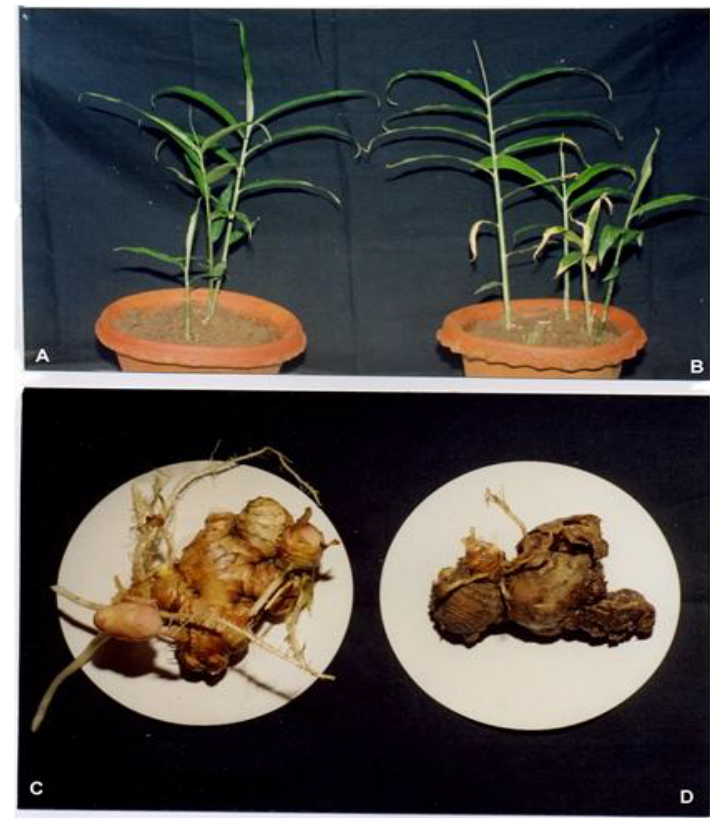

Figure 1: Ginger plants showing symptoms of rhizome rot disease. A - Healthy ginger plant; B - Infected ginger plant (4 weeks after inoculation and 8 weeks of sowing) showing wilting and drying of lower leaves and yellowing of leaf tips; C - Healthy rhizome of ginger (control); D - Infected rhizome of ginger (dark coloured putrefied rhizome).

\begin{tabular}{|c|c|c|c|c|c|c|}
\hline \multirow{2}{*}{ Incubation time (days)* } & \multicolumn{2}{|c|}{ Yellowing index/plant } & \multicolumn{2}{|c|}{${ }^{* *}$ Average fresh wt $(\mathrm{g})$ of rhizomes } & \multirow{2}{*}{$\%$ loss in fresh weight of rhizome } & \multirow{2}{*}{ Correlation coefficient } \\
\hline & Non inoculated & Inoculated & Non inoculated & Inoculated & & \\
\hline 7 & 0 & 0 & $39.40 \pm 0.57$ & $38.00 \pm 1.08$ & 3.55 & \multirow{4}{*}{$r=0.992$} \\
\hline 14 & 0 & 1.00 & $44.20 \pm 1.15$ & $38.95 \pm 1.61$ & 11.87 & \\
\hline 21 & 0 & 1.25 & $50.00 \pm 0.77$ & $37.50 \pm 1.65$ & 25.00 & \\
\hline 28 & 0 & 2.66 & $55.00 \pm 1.29$ & $36.15 \pm 3.23$ & 34.27 & \\
\hline \multicolumn{5}{|c|}{ CD at $5 \%$} & 8.73 & \\
\hline \multicolumn{5}{|c|}{$C D$ at $1 \%$} & 12.25 & \\
\hline
\end{tabular}

*Days after inoculation

${ }^{* *}$ Average of 4 rhizome seeds/treatment

Table 1: Effect of incubation period on the development of rhizome rot disease of ginger. 
Citation: Ghosh R (2015) Enzymatic Responses of Ginger Plants to Pythium Infection after SAR Induction. J Plant Pathol Microb 6: 283. doi:10.4172/2157-7471.1000283

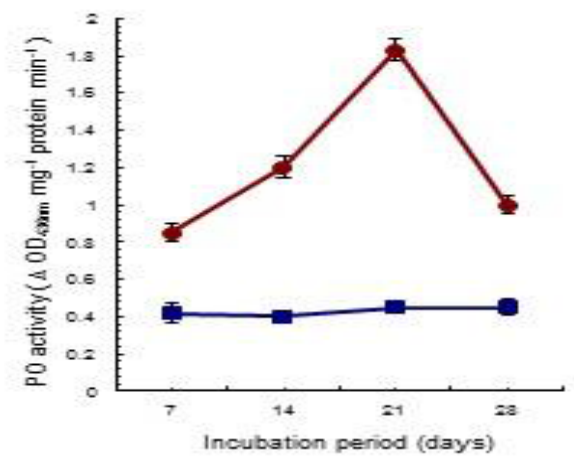

[A]

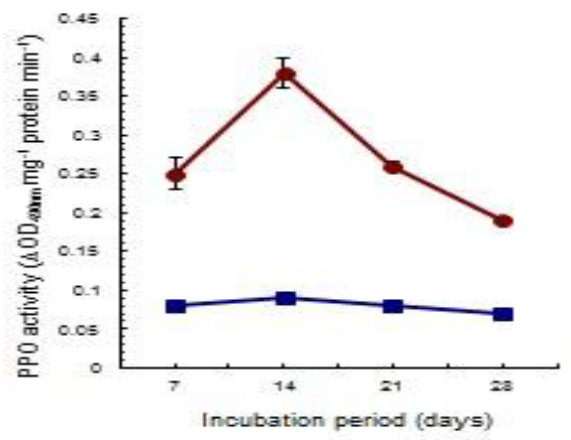

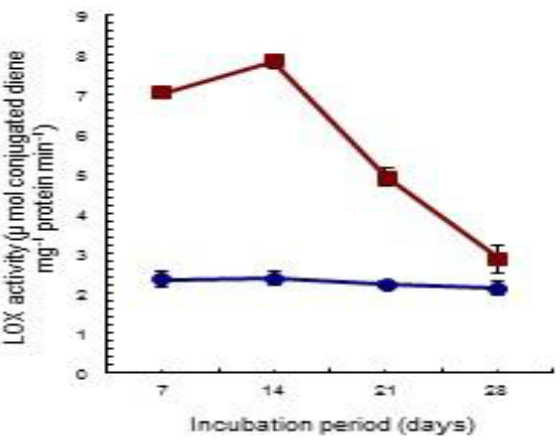

[C]

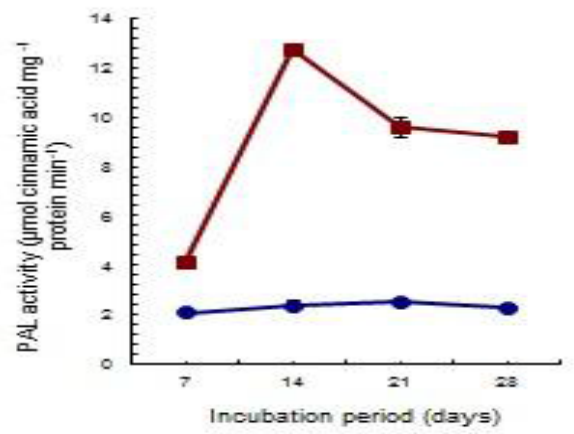

(B)

[D]

Figure 2: Activities of defence related enzymes in leaves of ginger after different periods of incubation with $P$. aphanidermatum .Red square line denoted untreated inoculated and blue circle line denoted ntreated noninoculated. A - PO; B - PPO; C- LOX; D : PAL.

\begin{tabular}{|c|c|c|c|c|c|c|}
\hline \multirow{2}{*}{ Treatment } & \multicolumn{2}{|c|}{ Yellowing index/plant } & \multicolumn{2}{|c|}{${ }^{* *}$ Average fresh wt $(\mathrm{g})$ of rhizomes } & \multicolumn{2}{|c|}{$\%$ loss in fresh wt of rhizomes } \\
\hline & 14 days* & 28 days & 14 days & 28 days & 14 days & 28 days \\
\hline \multicolumn{7}{|l|}{ Untreated } \\
\hline Non inoculated & 0 & 0 & $34.50 \pm 1.55$ & $46.00 \pm 1.29$ & & \\
\hline Inoculated & 1.16 & 2.20 & $30.85 \pm 1.17$ & $31.00 \pm 0.91$ & $10.57 \pm 0.68$ & $32.60 \pm 0.30$ \\
\hline \multicolumn{7}{|c|}{ Treated with SA (5 mM) } \\
\hline Non inoculated & 0 & 0 & $32.00 \pm 1.47$ & $42.87 \pm 1.16$ & & \\
\hline Inoculated & 0.50 & 0.83 & $30.67 \pm 1.34$ & $39.35 \pm 2.11$ & $4.15 \pm 1.92$ & $8.21 \pm 2.72$ \\
\hline \multicolumn{7}{|c|}{ Treated with ALE (10\%) } \\
\hline Non inoculated & 0 & 0 & $33.20 \pm 1.00$ & $44.00 \pm 1.58$ & & \\
\hline Inoculated & 0.28 & 0.71 & $32.35 \pm 1.96$ & $41.32 \pm 0.75$ & $2.56 \pm 1.40$ & $6.09 \pm 1.71$ \\
\hline CD at $5 \%$ & & & & & 4.10 & 6.52 \\
\hline $\mathrm{CD}$ at $1 \%$ & & & & & 5.76 & 9.37 \\
\hline
\end{tabular}

SA: Salicylic acid; ALE: Acalypha leaf extract

${ }^{*}$ Days after inoculation

${ }^{*}$ Average of 4 replicate rhizome seeds/treatment

Table 2: Effect of selected plant defence activators (SA and ALE) on disease development.

in SA-treated inoculated plants. The difference in PPO activity was not significant between SA- and ALE-treated non-inoculated plants. LOX activity increased in both SA- and ALE-treated plants up to 14 days of inoculation but markedly in SA-treated plants. PAL activity also increased in leaves of untreated inoculated as well as treated (SA or ALE) non-inoculated and inoculated plants. Activity was always higher in SA-treated than in ALE-treated plants (both non-inoculated and inoculated). Results showed that enzyme activities increased in ginger plants as a result of both treatment and inoculation. Highest activity was noted in treated inoculated plants. The rate of increase in treated inoculated plants were significantly higher in comparison to untreated inoculated plants $(\mathrm{P}<0.05)$ (Figure 3A-D).

In the present investigation results of pathogenicity test of $P$. aphanidermatum on a susceptible ginger cultivar showed that disease intensity increased with time up to 28 days but PPO, LOX and PAL activities increased up to 14 days following inoculation and then declined whereas PO activity reached their peaks on $21^{\text {st }}$ day after inoculation and then decreased sharply. Plant defence activators SA and ALE not only reduced rhizome rot disease significantly in ginger, but they also 
Citation: Ghosh R (2015) Enzymatic Responses of Ginger Plants to Pythium Infection after SAR Induction. J Plant Pathol Microb 6: 283. doi:10.4172/2157-7471.1000283

Page 5 of 6

\begin{tabular}{|c|c|c|c|c|c|c|c|c|}
\hline \multirow[t]{2}{*}{ Treatment } & \multicolumn{2}{|c|}{ PO activity $\underset{\left(\begin{array}{l}\left(\Delta D_{436 n m}\right. \\
\left.\min ^{-1}\right)\end{array} \mathrm{mg}^{-1} \text { protein }\right.}{ }$} & \multicolumn{2}{|c|}{$\begin{array}{l}\text { PPO activity }\left(\Delta O D_{490 \mathrm{~nm}} \mathrm{mg}^{-1}\right. \\
\left.\text { protein } \mathrm{min}^{-1}\right)\end{array}$} & \multicolumn{2}{|c|}{$\begin{array}{l}\text { LOX activity }(\mu \text { mol conjugated } \\
\text { diene } \mathrm{mg}^{-1} \text { protein } \text { min }^{-1}\end{array}$} & \multicolumn{2}{|c|}{$\begin{array}{l}\text { PAL activity ( } \mu \text { mol cinnamic acid } \\
\left.\mathrm{mg}^{-1} \text { protein } \mathrm{min}^{-1}\right)\end{array}$} \\
\hline & 14 days* & 28 days & 14 days* & 28 days & 14 days* & 28 days & 14 days* & 28 days \\
\hline \multicolumn{9}{|l|}{ Untreated } \\
\hline Non- inoculated & ${ }^{* * *} 0.38 \pm 0.02$ & $0.42 \pm 0.03$ & $0.07 \pm 0.006$ & $0.05 \pm 0.007$ & $2.35 \pm 0.27$ & $2.03 \pm 0.12$ & $2.28 \pm 0.12$ & $2.22 \pm 0.06$ \\
\hline Inoculated & $1.35 \pm 0.03$ & $1.12 \pm 0.06$ & $0.31 \pm 0.008$ & $0.22 \pm 0.002$ & $7.71 \pm 0.24$ & $2.67 \pm 0.14$ & $11.04 \pm 0.57$ & $10.08 \pm 0.48$ \\
\hline \multicolumn{9}{|c|}{ Treated with SA (5 mM) } \\
\hline Non-inoculated & $0.82 \pm 0.06$ & $0.80 \pm 0.04$ & $0.15 \pm 0.005$ & $0.13 \pm 0.005$ & $4.04 \pm 0.13$ & $3.83 \pm 0.16$ & $10.98 \pm 0.54$ & $9.54 \pm 0.88$ \\
\hline Inoculated & $2.05 \pm 0.03$ & $1.77 \pm 0.01$ & $0.85 \pm 0.14$ & $0.56 \pm 0.003$ & $9.45 \pm 0.22$ & $4.28 \pm 0.21$ & $18.42 \pm 0.78$ & $16.56 \pm 0.50$ \\
\hline \multicolumn{9}{|c|}{ Treated with ALE (10\%) } \\
\hline Non -inoculated & $0.72 \pm 0.05$ & $0.67 \pm 0.06$ & $0.14 \pm 0.011$ & $0.12 \pm 0.005$ & $3.64 \pm 0.18$ & $3.49 \pm 0.09$ & $9.24 \pm 0.77$ & $8.28 \pm 0.52$ \\
\hline Inoculated & $1.86 \pm 0.03^{*}$ & $1.65 \pm 0.11$ & $0.67 \pm 0.015$ & $0.42 \pm 0.02$ & $8.53 \pm 0.14$ & $3.85 \pm 0.30$ & $14.70 \pm 0.92$ & $12.84 \pm 1.53$ \\
\hline CD at $5 \%$ & 0.124 & 0.174 & 0.156 & 0.035 & 0.612 & 0.623 & 2.83 & 2.44 \\
\hline CD at $1 \%$ & 0.174 & 0.259 & 0.223 & 0.048 & 0.858 & 0.873 & 3.97 & 3.42 \\
\hline
\end{tabular}

SA: Salicylic acid; ALE: Acalypha leaf extract

*after inoculation

${ }^{* *}$ Average of 4 replicate rhizome seeds/treatment

$\star * * 3$ replicates/treatment

Table 3: Effect of plant defence activators (SA and ALE) on disease development and enzyme activities in ginger leaves.

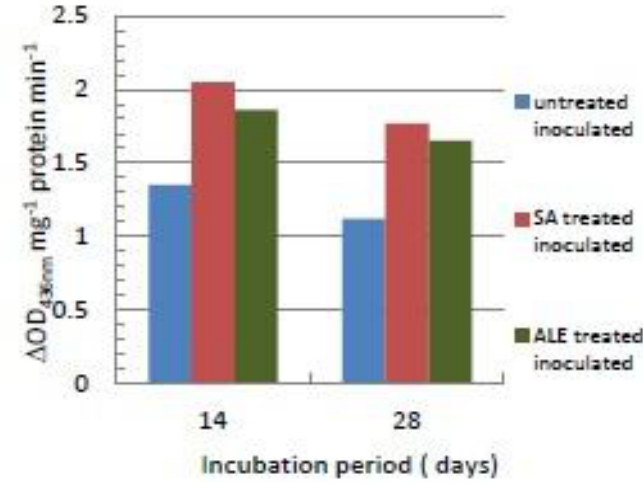

(A)

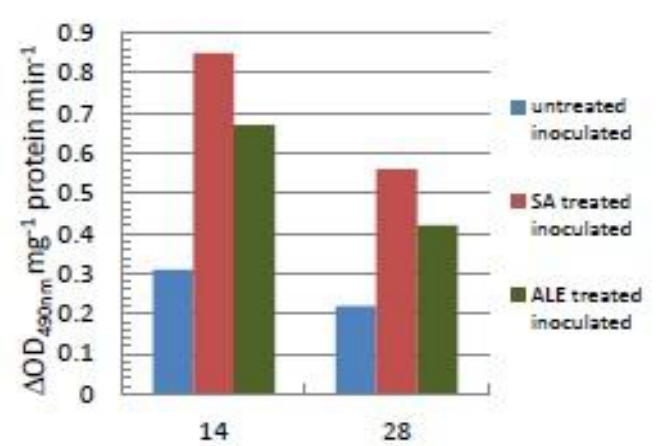

Incubation period (days)

(B)

PPO

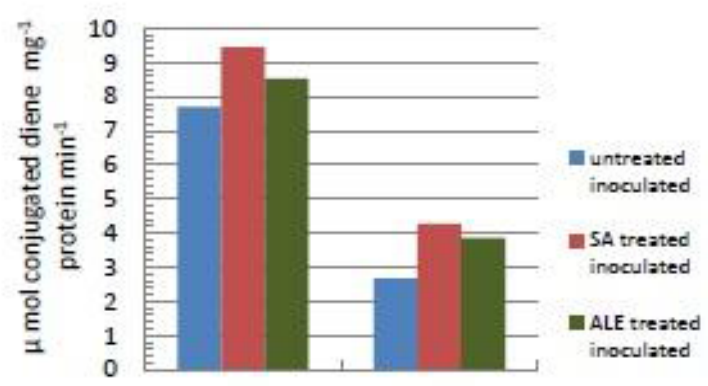

$14 \quad 28$

Incubation period (days)

(C)

LOX

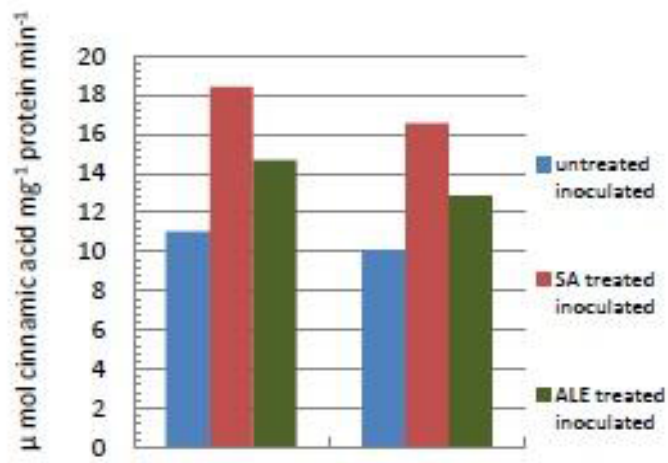

14

28

Incubation period (days)

(D)

PAL

Figure 3: Activities of defence related enzymes in leaves of untreated inoculated and treated inoculated ginger plants. 
enhanced activities of all four defence related enzymes in ginger leaves although the rate of increase was higher in untreated inoculated and treated non-inoculated plants in relation to their respective controls. The test enzymes preferentially responded to different kinds of defence activators. Systemic protection against P. aphanidermatum was induced in ginger by chemicals or specific herbal extracts. Among 12 plant defence activators tested, jasmonic acid $(5 \mathrm{mM})$ and $10 \%$ leaf extract of Acalypha indica (ALE) reduced disease significantly with concomitant increase of defence related proteins [18]. In this study, treated inoculated plants exhibited maximum activity for all four enzymes. SA stimulated all the four defence related enzymes than that of ALE. It was reported earlier that nonpathogenic rhizobacteria and a fungal pathogen P. aphanidermatum stimulated PO, PPO and PAL activities in cucumber roots [19]. Schneider [20] also recorded high enzyme (PO, PPO, PAL) activities in cucumber and tobacco after 2-3 days of treatment with various biotic and abiotic inducers including salicylic acid. Aqueous leaf extract of neem provided protection to barley against leaf stripe pathogen Drechslera graminis and enhanced PAL and TAL (Tyrosine ammonia lyase) activities along with rapid accumulation of fungitoxic phenolic compounds [21]. Induction of some defense related enzymes and phenolics in roots and shoots of two different genotypes of chickpea cultivars which were susceptible (L550) and resistant (ICCV10) to wilt disease treated with salicylic acid, spermine (Spm), SA+Spm and Fusarium oxysporum $\mathrm{f}$. sp. ciceri was investigated. Higher levels of polyphenol oxidase (PPO), phenylalanine ammonialyase (PAL), $\beta$-1,3-glucanase (PR-2) and phenolics were observed in roots and shoots of resistant cultivar than that of susceptible cultivar on treatment with elicitors and pathogen [22]. Involvement of LOX in induced resistance was also reported by a number of workers. Bohland et al. [23] observed that LOX activity increased in wheat leaves when treated with either glycopeptide elicitor from germtube of $P$. graminis f. sp. tritici or methyl jasmonate. Similarly, arachidonic acid $\left(10^{-8} \mu \mathrm{M}\right)$ also activated LOX activity in tuber tissues and enhanced resistance in potato against late blight [24]. Mitchell and Walters [25] reported that systemic resistance of barley to powdery mildew could be induced by potassium phosphate $(25 \mathrm{mM})$. Treatment of first leaves of barley with potassium phosphate led to significant increase in activities of PAL, PO and LOX in second leaves. Activities of PAL and PO increased further when second leaves of phosphate treated plants were inoculated with powdery mildew (Blumeria graminis f. sp. hordei Marchal).

The utilization of plants owns defence mechanism is the area of major interests in the management of pests and diseases. Result of present investigation clearly indicated that defence activators SA and ALE reduced disease significantly and also induced PO, PPO, LOX and PAL activities in ginger. Although enzyme activity increased in all cases, the rate of activity varied with the nature of enzymes and defence activators. In conclusion, it could be suggested that activation of defence related enzymes are quite likely to govern some of the basic mechanisms of biochemical resistance induced by SA and ALE in ginger plants against rhizome rot disease.

\section{Acknowledgement}

Financial assistance received from Department of Biotechnology, Government of India is gratefully acknowledged.

\section{References}

1. Hammerschmidt $R, K u A ̈ J(1995)$ Induced resistance to disease in plants. Kluwer, Dordrecht.

2. Kessmann H, Staub T, Hofmann C, Maetzke T, Herzog J, et al. (1994) Induction of systemic acquired disease resistance in plants by chemicals. Annu Rev Phytopathol 32: 439-459.
3. Sticher L, Mauch-Mani B, Métraux JP (1997) Systemic acquired resistance. Annu Rev Phytopathol 35: 235-270.

4. Dow M, Newman MA, von Roepenack E (2000) The induction and modulation of plant defense responses by bacterial lipopolysaccharides. Annu Rev Phytopathol 38: 241-261.

5. Durrant WE, Dong X (2004) Systemic acquired resistance. Annu Rev Phytopathol 42: 185-209.

6. Abd El-Rahman SSA, Mazen MM, Mohamed HI and Mahmoud NM (2012) Induction of defence related enzymes and phenolic compounds in lupin (Lupinus albus L.) and their effects on host resistance against Fusarium wilt. European Journal of Plant Pathology 134: 105-116

7. Thakker JK, Patel A, Dhandhukia PK (2013) Induction of Defense-Related Enzymes in Banana Plants: Effect of Live and Dead Pathogenic Strain of Fusarium oxysporum f. sp. cubense. ISRN Biotechnology.

8. Galliard T, Chan HWS (1980) Lipoxygenases: The Biochemistry of Plants Academic Press, New York.

9. Siedow JN (1991) Plant lipoxygenase: structure and function. Annu Rev Plant Physiol Plant Mol Biol 42: 145-188.

10. Andersson RA, Akita M, Pirhonen M, Gammelgard E, Valkonen JPT (2005) Moss-Erwinia pathosystem reveals possible similarities in pathogenesis and pathogen defense in vascular and nonvascular plants. J Gen Plant Pathol 71: 23-28.

11. Oliver JP, Castro A, Gaggero C, Cascon T, Schmelz EA, et al. (2009) Pythium infection activates conserved plant defense responses in mosses. Planta 230: 569-579

12. Winter PS, Bowman CE, Villani PJ, Dolan TE, Hauck NR (2014) Systemic acquired resistance in moss: further evidence for conserved defense mechanisms in plants. PLoS One 9: e101880.

13. Karmakar NC, Ghosh R, Purkayastha RP (2003) Plant defence activators inducing systemic resistance in Zingiber officinale Rosc. against Pythium aphanidermatum (Edson) Fitz. Indian Journal of Biotechnology 2: 591-595

14. Doubrava NS, Ralph AD and KuÄ J (1988) Induction of systemic resistance to anthrachose caused by Colletotrichum lagenarium in cucumber by oxalate and extracts from spinach. Physiol Mol Plant Pathol 33: 69-79.

15. Sadashivam S, Manickam A (1996) Biochemical Method, (2ndedn) New Age International, New Delhi.

16. Vick BA, Zimmerman DC (1976) Lipoxygenase and hydroperoxide lyase in germinating watermelon seedlings. Plant Physiol 57: 780-788.

17. Smith CJ, Milton JM, Williams JM (1995) Induction of phytoalexin synthesis in Medicago sativa (Lucerne) - Verticillium albo-atrum interaction. Handbook of phytoalexin metabolism and action. Marcel Dekker, Inc, New York.

18. Ghosh R, Purkayastha RP (2003) Molecular diagnosis and induced systemic protection against rhizome rot disease of ginger caused by Pythium aphanidermatum. Current Science 85: 1782-1787.

19. Chen C, Bélanger RR, Benhamou N, Paulitz TC (2000) Defense enzymes induced in cucumber roots by treatment with plant growth promoting rhizobacteria (PGPR) and Pythium aphanidermatum. Physiol Mol Plant Pathol 56: 13-23.

20. Schneider S (1994) Differential induction of resistance and enhanced enzyme activities in cucumber and tobacco caused by treatment with various abiotic and biotic inducers. Physiol Mol Plant Pathol 45: 291-304.

21. Paul PK, Sharma PD (2002) Azadirachta indica leaf extract induces resistance in barley against leaf stripe disease. Physiol Mol Plant Pathol 61: 3-13.

22. Raju S, Jaylakshmi SK, Sreeramulu K (2008) Comparative study on the induction of defense related enzymes in two different cultivars of chickpea (Cicer arietinum L) genotypes by salicylic acid, spermine and Fusarium oxysporum f. sp. Ciceri. Australian Journal of Crop Science 2: 121-140.

23. Bohland C, Balkenhohl T, Loers G, Feussner I, Grambow HJ (1997) Differentia Induction of Lipoxygenase Isoforms in Wheat upon Treatment with Rust Fungus Elicitor, Chitin Oligosaccharides, Chitosan, and Methyl Jasmonate. Plant Physiol 114: 679-685.

24. Ilinskaya L, Perekhod EA, Chalenko GI, Gerasimova NG, Romanenko EN, et al. (2000) Lipoxygenase activity in plants with induced resistance to disease. Russian Journal of Plant Physiology 47: 449-455

25. Mitchell AF, Walters DR (2004) Potassium phosphate induces systemic protection in barley to powdery mildew infection. Pest Manag. Sci 60: 126-134 